\title{
Kemampuan Berpikir Kritis Siswa dalam Pembelajaran Inquiry-Discovery
}

\author{
${ }^{1}$ Silvi Rosiva Rosdiana
}

${ }^{1}$ Prodi Pendidikan IPA, FKIP, Universitas Islam Lamongan

Email Korespondensi: silvirosiva@unisla.ac.id

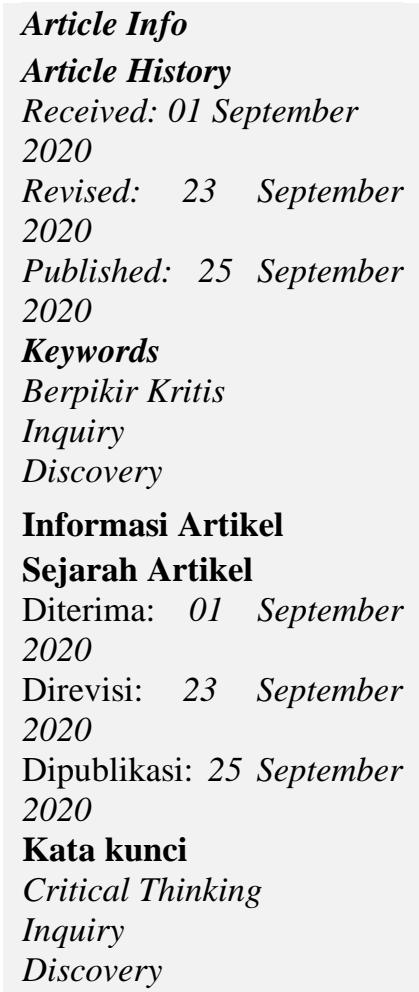

\begin{abstract}
The aims of this study is to measure the effect of the inquiry-discovery learning model on the improvement of students' critical thinking in static fluid material. The study was conducted on medium grade senior high school in the city of Malang. This study method was used a quasi-experimental. As a result, there was an increasing critical thinking skill in the experimental class than the control class. For the next study, measure the increasing in another high order thinking skills like focuses on the problem solving students' skill to reduce their misconception with using the same learning is the good expectation.
\end{abstract}

\begin{abstract}
Abstrak
Penelitian ini bertujuan untuk mengukur pengaruh model pembelajaran inquirydiscovery terhadap meningkatnya kemampuan berpikir kritis siswa pada materi fluida statis. Penelitian dilakukan kepada siswa SMA kelas XI di kota Malang. Penelitian ini menggunakan metode quasi-experiment sebagai metode untuk melaksanakan penelitian. Hasil yang diperoleh adalah adanya peningkatan dalam kelas eksperimen lebih tinggi daripada kelas kontrol. Penelitian selanjutnya diharapkan untuk mengukur peningkatan kemampuan berpikir tingkat tinggi lainnya, seperti kemampuan pemecahan masalah untuk mengurangi miskonsepsi mereka dengan menggunakan pembelajaran yang sama.
\end{abstract}

Sitasi: Rosdiana, Silvi Rosiva. (2020). Kemampuan Berpikir Kritis Siswa dalam Pembelajaran InquiryDiscovery. Science Education and Appplication Journal. 2(2). 101-111

\section{PENDAHULUAN}

Kemampuan untuk menalar, memecahkan masalah, hingga mengambil keputusan berdasarkan data atau fakta merupakan kemampuan yang sangat penting dan dibutuhkan pada abad ini. Ketiga kemampuan tersebut tergolong dalam kemampuan berpikir tingkat tinggi. Tercapainya kemampuan-kemampuan tersebut membutuhkan pemikiran yang kritis ketika seseorang harus mengidentifikasi atau mengkritisi suatu data yang apakah data tersebut mampu digunakan untuk menyimpulkan atau melakukan pengambilan keputusan dari suatu fenomena (Holmes, Wieman, \& Bonn, 2015). Sehingga, kemampuan berpikir kritis akan menjadi sangat penting dan dibutuhkan baik bagi seorang ilmuwan maupun seseorang pada lingkungan terkecil, yaitu siswa di sekolah. Dalam memasuki persaingan dunia, penting untuk mempersiapkan para siswa untuk melatih kemampuan dalam berkomunikasi, berkolaborasi, kreatif, inovatif, berpikir kritis, dan dapat memecahkan masalah secara efektif (Zivkovic, 2016).

Faktanya, melatih kemampuan-kemampuan yang tergolong berpikir tingkat tinggi, termasuk kemampuan berpikir kritis, kepada siswa tidak mudah. Salah satu kesulitan yang terjadi pada penerapan kemampuan berpikir kritis adalah dapat saja terjadi hubungan yang tidak jelas antara isi tes kemampuan berpikir kritis dan pengetahuannya pada materi tertentu (Tiruneh \& Cock, 
2017). Artinya, tes kemampuan berpikir kritis yang diberikan tidak mampu mendukung siswa untuk mengukur hasil pemahaman akhir dari materi yang telah dipelajari. Selain itu, kesulitan lain dalam melatih berpikir kritis berasal dari pembentukan disposisi dan kemampuan berpikir yang membutuhkan waktu jangka panjang dalam lingkungan belajar yang kondusif (Aizikovitsh-udi \& Cheng, 2015; McCormick, Clark, \& Raines, 2015). Disposisi dan kemampuan berpikir siswa sangat perlu dijaga perkembangannya agar tidak menghambat proses berpikir kritis siswa. Disposisi berpikir merupakan kebiasaan siswa dalam berpikir, sedangkan kemampuan berpikir yang dimaksud dapat dikembangkan melalui strategi pembelajaran. Dalam konteks yang lebih sempit, penelitian lain menunjukkan bahwa kemampuan berpikir kritis siswa yang rendah terindikasi pada kemampuan dalam mengidentifikasi informasi penting pada suatu fenomena yang disajikan (Manalo \& Uesaka, 2014). Kesulitan-kesulitan dalam melatihkan kemampuan berpikir kritis berdasarkan penelitian-penelitian sebelumnya telah menyebutkan hal yang kompleks, yaitu mulai dari dibutuhkannya strategi mengajar hingga pentingnya instrumen tes yang digunakan agar mampu mengukur kemampuan berpikir siswa pada materi tertentu yang sesuai agar proses berpikir kritis berkembang dengan meminimalisir faktor penghambat perkembangannya.

Sementara itu, untuk menjawab kesulitan pertama, bidang pendidikan saat ini telah mulai memasukkan unsur kegiatan belajar yang tidak hanya pasif (metode ceramah) tetapi juga kegiatan belajar aktif dan inovatif yang mampu melatih kemampuan berpikir siswa. Kemampuan berpikir kritis dapat ditingkatkan dengan memasukkan unsur teoritis dan empiris pada suatu pembelajaran (Howard et al., 2010; Häkkinen, 2017). Membangun hubungan antara informasi teoritis dan pengalaman kehidupan sehari-hari, serta mengubah informasi abstrak menjadi konkret hanya mungkin dilakukan dengan menggunakan laboratorium secara efektif dalam pembelajaran sains (Ş \& Özsoy, 2009). Kegiatan laboratorium mengarahkan siswa untuk melaksanakan kegiatan eksperimen secara bertahap. Dalam proses tersebut, siswa akan mengulangi langkah-langkah eksperimen dan mengingat pengetahuan teoritis yang telah diperoleh pada saat pembelajaran di kelas. Melakukan kegiatan eksperimen dengan memahami pengetahuan secara teoritisnya terlebih dahulu bisa disebut sebagai pembelajaran berbasis inquiry. Model pembelajaran inquiry merupakan pembelajaran yang mendorong siswa untuk melakukan penyelidikan dalam suatu kegiatan eksperimen (Wenning \& Khan, 2011) terhadap pemahaman teoritis dari suatu konsep yang telah diperoleh. Model ini dapat dikolaborasikan dengan pembelajaran berbasis penemuan, di mana proses belajar dapat diawali dengan penyelidikan terhadap suatu masalah hingga akhirnya diperoleh suatu penemuan terhadap suatu konsep yang sedang dipelajari. Proses penyelidikan hingga penemuan merupakan kegiatan pembelajaran secara empiris, sedangkan hasil dari penemuan yang dibandingkan dengan konsep yang sedang dipelajari merupakan pembelajaran secara teoritisnya. Beberapa penelitian mengungkapkan bahwa tinjauan empirik dan teoritis dalam pembelajaran dibutuhkan untuk mengetahui bagaimana hubungan pembelajaran sains dan bentukan pengetahuan siswa (Veresov, 2016; Müller et al., 2016; Rönnebeck, Bernholt, \& Ropohl, 2016). Maka, dengan menerapkan pembelajaran inquiry-discovery akan efisien apabila digunakan dengan tujuan untuk meningkatkan kemampuan berpikir kritis siswa.

Pembelajaran inquiry-discovery dibelajarkan dengan cara menghubungkan fenomena dalam kehidupan sehari-hari dengan kegiatan eksperimen yang akan dilakukan, agar mampu melatih kemampuan berpikir kritis. Karena, kemampuan berpikir kritis memiliki indikator sebagai pengukur tinggi rendahnya kemampuan tersebut. Indikator pertama pada kemampuan berpikir kritis adalah kemampuan dalam merumuskan masalah. Perumusan masalah dinilai berdasarkan bagaimana seorang siswa mampu untuk mengidentifikasi masalah yang berasal dari suatu fenomena. Indikator yang lain adalah berupa kemampuan untuk membangun kemampuan dasar, membuat kesimpulan, memberikan penjelasan lebih lanjut, dan mengatur strategi. Beberapa indikator-indikator tersebut juga terdapat di dalam indikator kemampuan pemecahan masalah. Hal ini menunjukkan bahwa kemampuan berpikir kritis dan kemampuan pemecahan 
masalah sama-sama berada pada kategori kemampuan berpikir. Sehingga dapat disimpulkan, bahwa untuk mengembangkan kemampuan berpikir kritis siswa, siswa juga membutuhkan kemampuan pemecahan masalah (Ozyurt, 2015) untuk dimiliki terlebih dahulu. Tinggi rendahnya kemampuan pemecahan masalah yang dimiliki siswa dapat diidentifikasi melalui tiga hal, yaitu bagaimana cara siswa mengategorikan variabel-variabel dalam suatu permasalahan, bagaimana siswa menentukan pendekatan pemecahan masalah yang akan digunakan, dan bagaimana metakognisi mereka dalam menjawab suatu permasalahan (Docktor \& Mestre, 2014).

Adapun permasalahan yang dimunculkan dalam suatu bentuk soal pengukur kemampuan pemecahan masalah dan kemampuan berpikir kritis (instrumen soal) sebaiknya berupa permasalahan yang berhubungan dengan fenomena dalam kehidupan sehari-hari atau berupa persoalan yang konseptual. Karena, tujuan dari dari pendidikan di abad 21 adalah menghasilkan siswa-siswa lulusan yang berkompeten dan profesional dalam melakukan pekerjaannya di dunia nyata, sehingga kemampuan berpikir kritis maupun pemecahan masalah sangatlah penting untuk dikembangkan (Kivunja, 2014). Dengan demikian, persoalan yang konseptual yang diberikan pada siswa harus mengandung indikator-indikator yang dibutuhkan untuk melatih kemampuan bepikir siswa, baik itu kemampuan pemecahan masalah atau kemampuan berpikir kritis. Dengan adanya fenomena yang dimunculkan pada suatu persoalan, maka siswa dapat ditugaskan untuk mengidentifikasi informasi atau data-data yang berguna di dalamnya, menjelaskan konteks yang sedang dibahas, memberikan asumsi-asumsi yang dimiliki, serta mengambil keputusan dan memberikan kesimpulan sebagai solusi atau penyelesaian dari persoalan. Sehingga, hal tersebut sekaligus menjawab kesulitan kedua mengenai instrumen tes yang harus sesuai dengan indikator kemampuan berpikir siswa pada materi tertentu yang sedang diukur.

Indikator-indikator penyusun kemampuan berpikir kritis dapat dicapai dengan melakukan teknik pengajaran yang efektif (Loes, Salisbury, \& Pascarella, 2015), seperti melalui pembelajaran inquiry-discovery. Karena dalam praktiknya, proses pembelajarannya juga dihubungkan langsung dengan fenomena-fenomena di sekitar siswa. Maka, melalui pembelajaran inquiry-discovery dengan serangkaian kegiatan eksperimen secara berulang, kemampuan berpikir kritis siswa yang memiliki kemampuan pemecahan masalah tinggi dan rendah akan meningkat. Penelitian ini juga menggunakan model pembelajaran lain sebagai pembanding, yaitu Unit Kegiatan Belajar Mandiri (UKBM) yang saat ini sedang diterapkan pada kurikulum pendidikan di Indonesia. Sedangkan, topik yang diambil dalam penelitian adalah Fluida Statis. Fluida statis terbagi menjadi beberapa sub topik, diantaranya adalah tekanan hidrostatis, hukum Archimedes, dan Aplikasi hukum Archimedes.

\section{METODE}

Metode yang digunakan dalam penelitian ini adalah quasi-experiment, karena penelitian ini bertujuan untuk mengukur kemampuan berpikir kritis siswa dalam memecahkan permasalahan dalam bentuk kegiatan eksperimen dan soal dalam bentuk tes. Penelitian ini dilakukan di kelas SMAN 5 Malang. Populasi penelitian ini adalah seluruh siswa kelas XI IPA SMAN 5 Malang yang tersebar dalam tujuh kelas. Pemilihan sampel dilakukan dengan teknik cluster random sampling terhadap seluruh kelas XI IPA, kemudian dipilih empat kelas yang terdiri dari empat kelas, yaitu dua kelas eksperimen dan dua kelas kontrol. Masing-masing kelas eksperimen dan kelas kontrol berjumlah 70 siswa. Kelas eksperimen merupakan kelas yang diberikan intervensi melalui pembelajaran inquiry-discovery. Sedangkan kelas kontrol merupakan kelas yang menggunakan pembelajaran konvensional.

Langkah-langkah dalam penelitian ini terbagi menjadi beberapa tahap seperti dalam diagram berikut ini: 


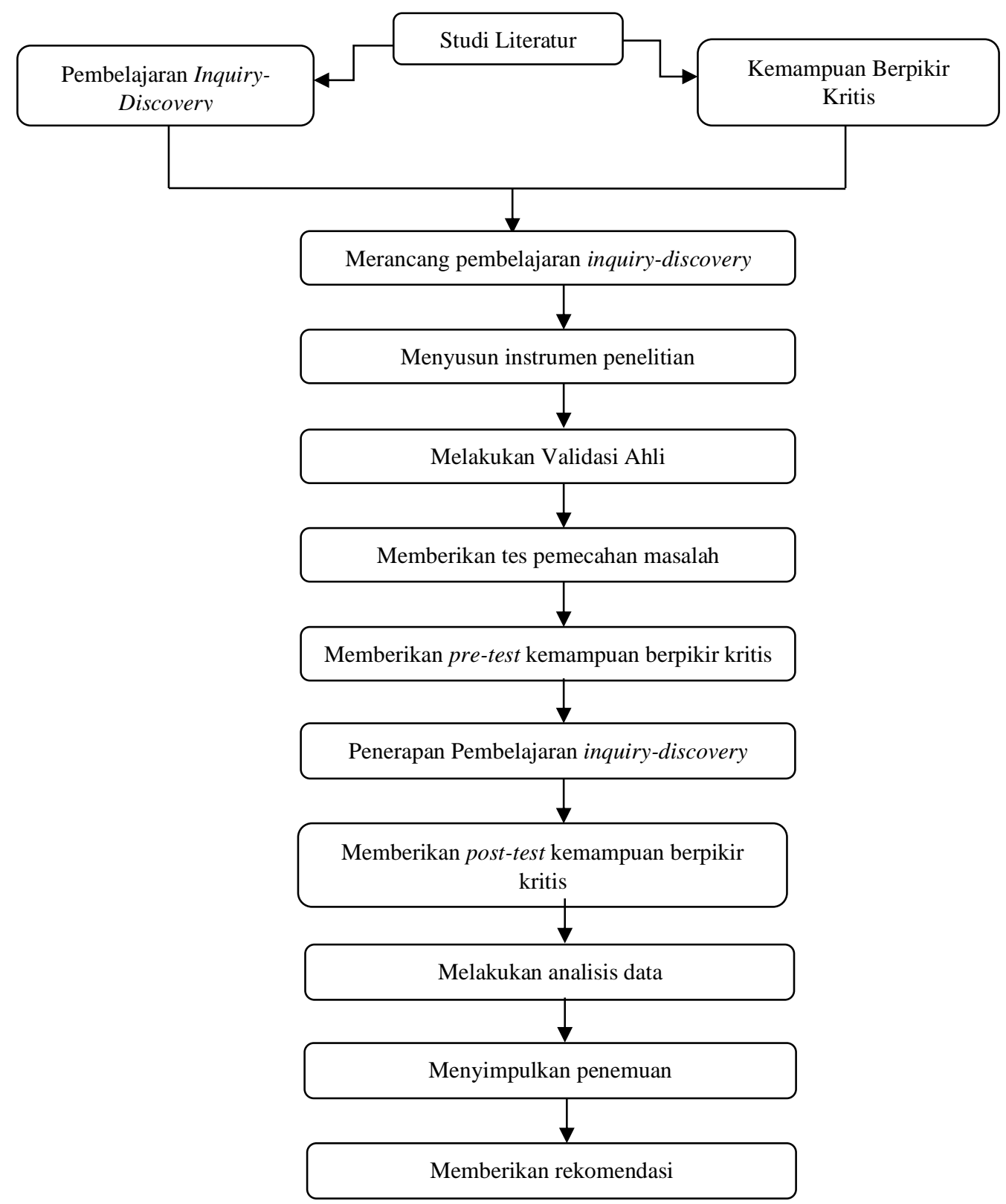

Gambar 1. Diagram Langkah-Langkah Penelitian

Instrumen utama yang digunakan dalam penelitian ini adalah tes kemampuan pemecahan masalah dan kemampuan berpikir kritis. Tes kemampuan pemecahan masalah terdiri dari empat soal sesuai dengan indikator kemampuan pemecahan masalah. Sedangkan tes kemampuan berpikir kritis terdiri dari tujuh soal sesuai dengan indikator kemampuan berpikir kritis. Tes kemampuan pemecahan masalah diberikan terlebih dahulu sebelum pre-test kemampuan berpikir kritis. Tes kemampuan pemecahan masalah diberikan untuk mengetahui kemampuan pemecahan masalah siswa yang tinggi dan rendah dari 70 siswa pada masingmasing kelas eksperimen dan kelas kontrol. Kemudian diambil 46 siswa dari masing-masing kelas yang terbagi menjadi 23 siswa dengan kemampuan pemecahan masalah tinggi dan 23 siswa dengan kemampuan pemecahan masalah rendah. Pre-test kemampuan berpikir kritis kemudian diberikan setelah tes kemampuan pemecahan masalah. Kemudian, diberikan lima kali pertemuan untuk penerapan pembelajaran inquiry-discovery pada kelas eksperimen dan pembelajaran UKBM pada kelas kontrol. Selang dua minggu dari pembelajaran terakhir yang diberikan, dilakukan post-test kemampuan berpikir kritis. 
Analisis data didasarkan pada data kuantitatif yang telah dikumpulkan. Data kuantitatif diperoleh dari nilai hasil tes. Hasil analisis data kuantitatif kemudian diinterpretasi untuk mendapatkan kesimpulan. Analisis statistik yang digunakan untuk mengetahui adanya peningkatan kemampuan berpikir kritis setelah diberikan perlakuan adalah analisis anava dua jalur.

\section{HASIL DAN PEMBAHASAN}

Keseluruhan hasil pencapaian kemampuan berpikir kritis siswa pada kelas eksperimen dan kelas kontrol setelah dan sesudah perlakuan yang dianalisis menggunakan teknik analisis statistik menunjukkan hasil yang cukup baik dalam hal peningkatan. Dengan jumlah siswa sejumlah 46 pada masing-masing kelas, kemampuan berpikir kritis siswa pada kelas yang diberikan pembelajaran inquiry-discovery lebih tinggi jumlah nilai peningkatannya daripada kelas yang menggunakan pembelajaran UKBM, baik pada siswa dengan kemampuan pemecahan masalah yang rendah maupun yang tinggi. Hasil analisis menunjukkan $F_{\text {hitung }}>$ $\mathrm{F}_{\text {tabel, }}$ yaitu 14,637 > 3,949, yang mengartikan bahwa peningkatan kemampuan berpikir kritis pada kelas eksperimen lebih tinggi daripada kelas kontrol.

Hasil analisis statistik penelitian yang menunjukkan adanya peningkatan pada kemampuan berpikir kritis dapat ditunjukkan melalui nilai rata-rata pre-test dan post-test, seperti yang ditunjukkan Tabel 1.

Tabel 1. Data Pre-test dan Post-test Kemampuan Berpikir Kritis

\begin{tabular}{ccccc}
\hline \multirow{2}{*}{ Kelas } & \multicolumn{2}{c}{ Nilai Rata-Rata Pre-Test } & \multicolumn{2}{c}{ Nilai Rata-Rata Post-Test } \\
\cline { 2 - 5 } & KPM Rendah & KPM Tinggi & KPM Rendah & KPM Tinggi \\
\hline Eksperimen & 30,4 & 35,9 & 38,3 & 45,6 \\
\hline Kontrol & 33,3 & 36,6 & 37,5 & 42,8 \\
\hline
\end{tabular}

Berdasarkan pada Tabel 1, peningkatan nilai rata-rata kemampuan berpikir kritis kelas eksperimen lebih tinggi daripada peningkatan nilai rata-rata kemampuan berpikir kritis pada kelas kontrol. Nilai rata-rata kemampuan berpikir kritis pada kelas eksperimen yang memiliki kemampuan pemecahan masalah (KPM) rendah mengalami peningkatan nilai sebesar 7,9 poin, sedangkan siswa yang memiliki KPM tinggi mengalami peningkatan nilai sebesar 9,7 poin. Dibandingkan dengan nilai rata-rata kemampuan berpikir kritis pada siswa dengan KPM rendah yang mengalami peningkatan nilai lebih kecil, yaitu 4,2 poin, sedangkan siswa dengan KPM tinggi mengalami peningkatan nilai sebesar 6,2 poin. Nilai rata-rata kemampuan berpikir kritis juga dapat digambarkan dalam bentuk diagram seperti Gambar 2.

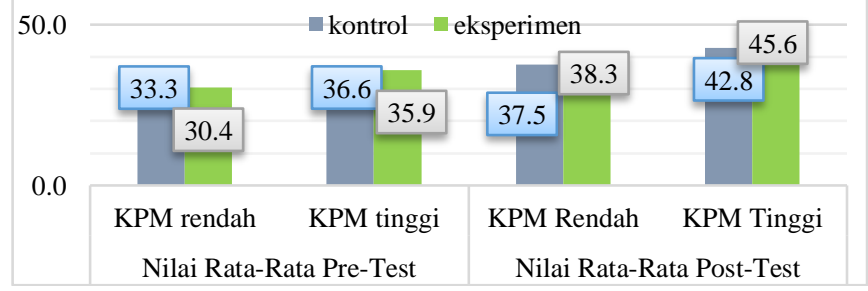

Gambar 2. Diagram Batang Nilai Rata-Rata Kemampuan Berpikir Kritis Siswa

Peningkatan kemampuan berpikir kritis juga dapat diamati pada setiap sub topik materi fluida statis. Sub topik materi fluida statis yang digunakan dalam penelitian ini diantaranya adalah tekanan hidrostatis, hukum Archimedes, dan Aplikasi hukum Archimedes. Gambar 3 menunjukkan pencapaian kemampuan berpikir kritis siswa pada setiap sub topik materi fluida statis, baik pada kelas eksperimen maupun kelas kontrol pada proses pembelajarannya. 


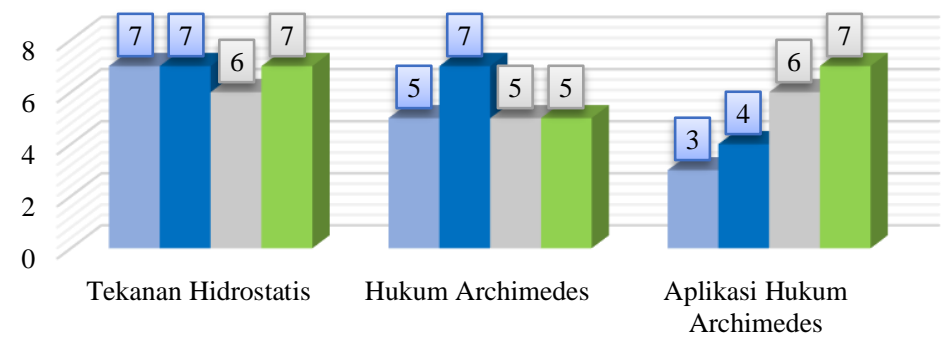

Nilai Rata-rata Kelas Kontrol KPM Rendah
Nilai Rata-rata Kelas Kontrol KPM Tinggi
Nilai Rata-rata Kelas Eksperimen KPM rendah
Nilai Rata-rata Kelas Eksperimen KPM Tinggi

Gambar 3. Diagram Batang Nilai Rata-Rata Post-Test Kemampuan Berpikir Kritis Siswa pada Setiap Sub Topik

Diagram batang pada Gambar 3 menunjukkan bahwa nilai rata-rata post-test kemampuan berpikir kritis pada kelas kontrol berdasarkan KPM tinggi dan rendah lebih tinggi pada sub topik tekanan hidrostatis dan hukum Archimedes daripada nilai rata-rata post-test kemampuan berpikir kritis pada kelas eksperimen. Sebaliknya, pada sub topik aplikasi hukum Archimedes, nilai rata-rata post-test kemampuan berpikir kritis pada kelas eksperimen dengan KPM tinggi dan rendah lebih tinggi daripada kelas kontrol.

Temuan penelitian menunjukkan bahwa kemampuan berpikir kritis siswa yang belajar menggunakan pembelajaran inquiry-discovery (kelas eksperimen) mengalami peningkatan yang lebih tinggi daripada siswa yang belajar menggunakan UKBM (kelas kontrol). Namun, meskipun mengalami peningkatan yang lebih tinggi, nilai rata-rata post-test kemampuan berpikir kritis siswa pada kelas eksperimen, baik yang memiliki KPM tinggi maupun rendah, pada setiap sub topiknya tidak lebih tinggi daripada yang ditemukan pada kelas kontrol. Kedua hasil temuan dapat dijabarkan sebagai berikut.

\section{Peningkatan Kemampuan Berpikir Kritis Siswa pada Pembelajaran Inquiry-Discovery Berdasarkan Tingkatan Kemampuan Pemecahan Masalah}

Penelitian ini menemukan bahwa kemampuan berpikir kritis siswa pada pembelajaran inquirydiscovery berdasarkan kemampuan pemecahan masalah tinggi dan rendah, lebih tinggi daripada kemampuan berpikir kritis siswa pada pembelajaran UKBM. Temuan ini berasal dari hasil analisis statistik anava dua jalur yang kemudian dibuktikan dengan hasil nilai rata-rata pre dan post tes pada kedua pembelajaran (lihat Tabel 1).

Dalam proses pembelajaran, terdapat perlakuan kepada siswa yang berbeda dari kedua jenis kelas. Siswa yang belajar menggunakan inquiry-discovery dituntut aktif dengan cara melakukan kegiatan laboratorium yang berisi tugas penyelidikan hingga penemuan secara berkelompok dan juga menyelesaikan suatu permasalahan. Sedangkan siswa yang belajar menggunakan UKBM dituntut aktif dengan cara membaca dan mendiskusikan secara bersamasama bahan bacaan atau konsep yang sedang dipelajari kemudian memecahkan permasalahan pada soal-soal yang telah tersedia pada buku siswa.

Sebagaimana dari beberapa penelitian sebelumnya tentang pembelajaran inquiry ataupun discovery, bahwa dalam menerapkan pembelajaran tersebut penting untuk diberikannya Lembar Kerja Siswa (LKS) untuk memudahkan proses saat kegiatan laboratorium dimulai. LKS diberikan pada setiap kegiatan penyelidikan materi yang berbeda (Aizikovitsh-udi \& Cheng, 2015). Dalam LKS terdapat pertanyaan analisis yang dimulai dengan hubungan sederhana dan berlanjut pada keterampilan tingkat tinggi (Gregorio, 2015). Oleh karena itu, 
dalam penelitian ini juga disediakan LKS untuk memudahkan kegiatan laboratorium yang dilaksanakan oleh siswa, yang disesuaikan dengan model pembelajaran. Adapun contoh bagian LKS yang telah dikerjakan oleh siswa dalam Gambar 4, sebagai berikut.

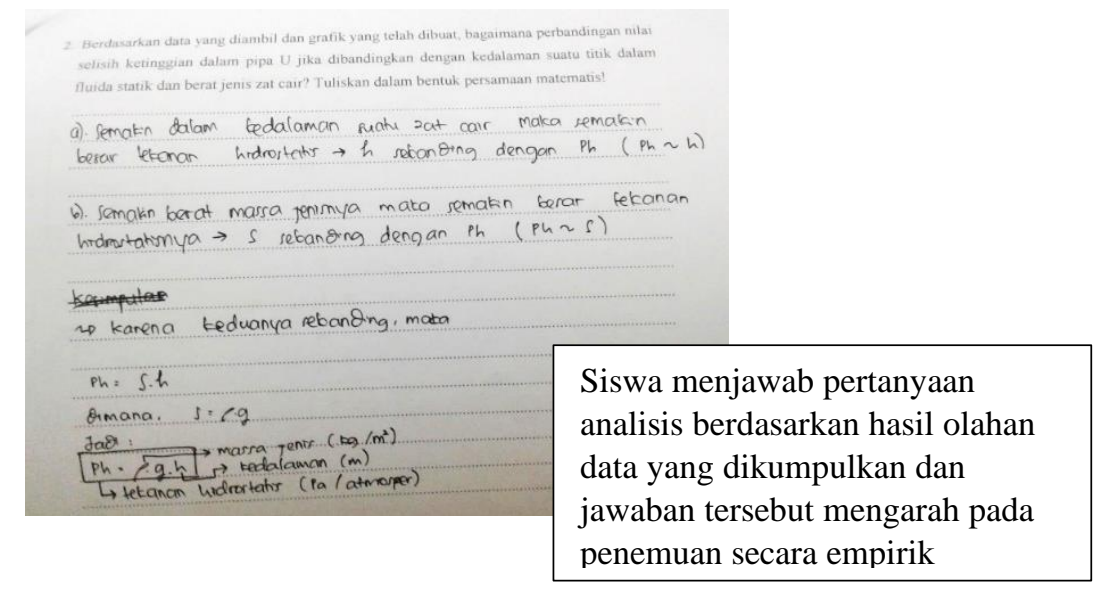

Gambar 4. Jawaban Siswa pada Pertanyaan Analisis dalam LKS

Gambar 4 merupakan gambar dari jawaban siswa atas salah satu bentuk pertanyaan analisis di dalam LKS yang mengarah pada penemuan secara empirik. Jawaban siswa tersebut tidak lepas dari hasil-hasil kumpulan dan olahan data yang telah dilakukan setelah percobaan. Setelah dilakukan penemuan secara empirik, LKS menyajikan pertanyaan yang mengarah pada penemuan secara teoritis, seperti yang ditunjukkan pada Gambar 5.

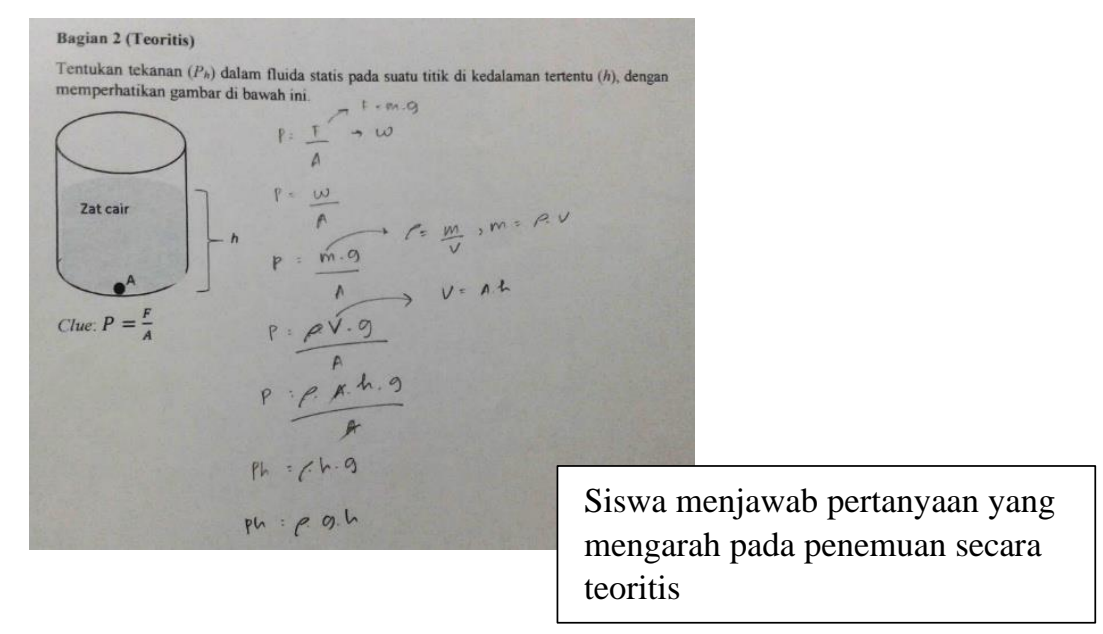

Gambar 5. Jawaban Siswa pada Pertanyaan Analisis dalam LKS

Gambar 4 dan 5 menunjukkan bahwa penemuan secara empirik dan teoritis merupakan hasil dari proses penyelidikan yang membutuhkan kemampuan berpikir kritis yang cukup baik. Proses pengerjaan siswa pada LKS menunjukkan bahwa model pembelajaran inquirydiscovery dapat membantu siswa mengasah dan meningkatkan kemampuan berpikir kritisnya. Hal ini karena LKS dibuat sedemikian rupa, di mana perintah-perintah di dalamnya bertujuan untuk menguasai indikator kemampuan berpikir kritis siswa, seperti mengidentifikasi fenomena, merumuskan masalah, hingga pengambilan keputusan, dan lain sebagainya. Sehingga kemampuan berpikir kritis siswa terlatih secara otomatis, karena baik proses pembelajaran maupun bentuk tes kemampuan berpikir kritisnya mengarah pada indikator yang sama. Dapat juga dikatakan bahwa proses pembelajaran inquiry-discovery ini mendukung pencapaian hasil kemampuan berpikir kritis siswa. 
Beberapa penelitian tentang pembelajaran inquiry ataupun pembelajaran discovery dapat memberikan dampak positif terhadap meningkatnya kemampuan berpikir kritis. Peningkatan kemampuan berpikir kritis siswa melalui pembelajaran inquiry sesuai untuk penerapan terhadap praktikum sesungguhnya dan membantu memenuhi pengetahuan dan kemampuan yang diminta sebagai syarat dalam membantu siswa mencapai kesuksesan dalam belajar (Thaiposri \& Wannapiroon, 2015). Selain itu, pembelajaran penemuan terbimbing juga memiliki dampak positif dalam mengembangkan kemampuan berpikir kritis siswa dan meminta siswa untuk membuat pemikiran lebih dalam saat menyelesaikan masalah (Duran, 2016; Wang, 2018). Sedangkan, penelitian sebelumnya tentang pembelajaran inquirydiscovery menyatakan bahwa pembelajaran ini efektif dalam mengurangi miskonsepsi siswa (Basman, Arifin, \& Muris, 2016). Berkurangnya miskonsepsi siswa dalam pembelajaran inquiry-discovery terjadi selama proses pembelajarannya (Wartono, Batlolona, \& Huda, 2018). Pengurangan miskonsepsi ideal dengan terbentuknya pemahaman yang utuh tanpa terpotongpotong, sehingga pembelajaran inquiry-discovery mampu mendukung meningkatkan kemampuan berpikir tingkat tinggi (Wartono, Hudha, \& Batlolona, 2017), yang di dalamnya juga termasuk kemampuan berpikir kritis siswa. maka, sejalan dengan penelitian-penelitian sebelumnya bahwa pembelajaran inquiry-discovery ini mampu memberikan dampak positif terhadap kemampuan berpikir kritis siswa.

\section{Hasil Kemampuan Berpikir Kritis Siswa Menggunakan Pembelajaran Inquiry- Discovery Tidak Lebih Baik Daripada Pembelajaran UKBM Berdasarkan Tingkatan Kemampuan Pemecahan Masalah Pada Sub Materi Fluida Statis}

Peningkatan kemampuan berpikir kritis pada siswa yang belajar menggunakan pembelajaran inquiry-discovery diketahui lebih tinggi dari pada siswa yang belajar menggunakan pembelajaran UKBM. Namun, setelah dianalisis pada nilai rata-rata post-test, siswa yang belajar menggunakan inquiry-discovery memiliki nilai rata-rata yang lebih rendah daripada siswa yang belajar menggunakan UKBM pada dua sub topik, sedangkan pada satu sub topik yang lain memiliki nilai rata-rata yang lebih tinggi. Nilai rata-rata post-test yang lebih rendah pada pembelajaran inquiry-discovery terdapat pada sub topik tekanan hidrostatis dan hukum Archimedes, sedangan nilai rata-rata post-test yang lebih tinggi terdapat pada sub topik saja, yaitu aplikasi hukum Archimedes. Pada sub topik aplikasi hukum Archimedes, siswa yang menggunakan pembelajaran inquiry-discovery memperoleh nilai rata-rata post-test yang lebih tinggi, karena mereka telah memahami dengan benar tentang konsep bahwa faktor utama yang mempengaruhi keadaan suatu benda dapat terapung, melayang dan tenggelam adalah massa jenis benda dan massa jenis fluida. Hasil tersebut dapat diperoleh karena didukung selama proses pembelajaran, yaitu melakukan identifikasi permasalahan pada fenomena kapal laut dan kapal selam yang diputarkan melalui video. Setelah itu siswa melakukan kegiatan laboratorium (penyelidikan dan penemuan) sebagai solusi dari permasalahan yang telah diidentifikasi di awal. Hal ini berarti bahwa eksperimen yang telah dilakukan siswa memiliki kontribusi positif terhadap pemahaman siswa. Sedangkan, nilai rata-rata post-test yang lebih rendah diperoleh pada kelas dengan pembelajaran UKBM, karena pada pembelajaran ini siswa tidak diberikan kesempatan untuk melakukan kegiatan laboratorium selama proses pembelajarannya. Kegiatan laboratorium hanya diberikan dengan cara demonstrasi yang dilakukan oleh guru. Dari kedua fenomena ini dapat disimpulkan bahwa pembelajaran yang dilakukan secara empirik mampu membuat siswa memahami konsep dengan baik (Ardianto \& Rubini, 2016).

Pembelajaran UKBM tidak dilakukan dengan memberikan pembelajaran dengan siklus empirik, namun berfokus pada pemahaman konsep dengan melatih siswa-siswa menyelesaikan persoalan yang cenderung berupa penerapan soal secara matematis. Hal inilah yang menyebabkan siswa yang belajar menggunakan pembelajaran UKBM memperoleh nilai ratarata post-test yang lebih tinggi daripada pembelajaran inquiry-discovery pada sub topik tekanan hidrostatis dan hukum Archimedes. Karena, beberapa soal pada subtopik tekanan hidrostatis 
dan hukum Archimedes dibuat dalam bentuk penerapan konsep matematis. Berdasarkan hasil jawaban pekerjaan siswa pada kelas inquiry-discovery, siswa telah menggunakan konsep matematis yang tepat sebagai penyelesaian dari soal, namun kurangnya latihan dalam mengerjakan soal-soal, beberapa siswa tidak teliti dalam melakukan substitusi data ke dalam rumusan matematis yang telah mereka tulis, sehingga hasil akhir atau nilai akhir yang diperoleh tidak benar. Adapun penyebab yang lain adalah beberapa siswa lainnya menggunakan konsep yang salah sebagai solusi dari pengerjaan soal. Kebanyakan siswa menggunakan konsep tekanan pada zat padat ketika sedang menyelesaikan soal tekanan hidrostatis, sehingga jawaban mereka bernilai salah. Sehingga, selain faktor ketelitian, miskonsepsi juga menjadi faktor yang membuat pencapaian kemampuan berpikir kritis siswa yang menggunakan pembelajaran inquiry-discoevry pada subtopik tekanan hidrostatis dan hukum Archimedes lebih rendah.

\section{KESIMPULAN}

Berdasarkan hasil analisis secara keseluruhan menyatakan bahwa meskipun tidak menutup kemungkinan tercapainya hasil kemampuan berpikir kritis pada tes akhir yang masih lebih rendah dalam kelas yang menggunakan pembelajaran inquiry-discovery, namun peningkatan kemampuan berpikir kritis yang dicapai, baik pada siswa yang memiliki kemampuan rendah maupun tinggi, memiliki hasil yang lebih tinggi daripada peningkatan kemampuan berpikir kritis yang terjadi pada siswa yang menggunakan UKBM. Adapun penyebab diperolehnya hasil yang rendah pada nilai rata-rata kemampuan berpikir kritis siswa pada kelas dengan pembelajaran inquiry-discovery adalah karena adanya ketidaktelitian dan miskonsepsi oleh siswa, serta kurangnya pemberian latihan pengerjaan soal dalam bentuk penerapan matematis.

\section{SARAN}

Penelitian menggunakan pembelajaran inquiry-discovery dapat dilakukan untuk mengetahui pengaruhnya terhadap kategori kemampuan berpikir tingkat tinggi lainnya, seperti terhadap kemampuan berpikir kreatif siswa atau kemampuan berargumentasi siswa. Selain itu, untuk meningkatkan kemampuan berpikir kreatif, siswa perlu dilatih untuk menyelesaikan permasalahan fisika yang bersifat autentik, sehingga pembelajaran lebih bermakna bagi siswa dan juga mencegah berkembangnya miskonsepsi siswa.

\section{UCAPAN TERIMA KASIH}

Penulis mengucapkan terima kasih secara khusus kepada guru Fisika SMAN 5 Malang, Ibu Wiwiek Mulyani, serta siswa-siswa kelas XI IPA SMAN 5 Malang dan kepala sekolah SMAN 5 Malang, Bapak Anis Isrofin, yang telah memberikan penulis kesempatan emas serta mendukung penulis untuk melakukan penelitian pendidikan pada topik pembelajaran inquirydiscovery terhadap kemampuan berpikir kritis siswa.

\section{DAFTAR PUSTAKA}

Aizikovitsh-udi, E., \& Cheng, D. (2015). Developing Critical Thinking Skills from Dispositions to Abilities: Mathematics Education from Early Childhood to High, (March), 455-462.

Ardianto, D., \& Rubini, B. (2016). Comparison of students' scientific literacy in integrated science learning through model of guided discovery and problem based learning. Jurnal Pendidikan IPA Indonesia, 5(1), 31-37. https://doi.org/10.15294/jpii.v5i1.5786

Basman, T., Arifin, A., \& Muris, M. (2016). The development of discovery-inquiry learning model to erduce the science misconceptions of junior high school students. International Journal of Environmental \& Science Education, 11(12), 5676-5686.

Conference, I., English, L., \& Language, A. (2016). A Model of Critical Thinking as an Important Attribute for Success in the 21st Century, 232(April), 102-108. https://doi.org/10.1016/j.sbspro.2016.10.034 
Docktor, J. L., \& Mestre, J. P. (2014). Synthesis of discipline-based education research in physics. Physical Review Special Topics - Physics Education Research, 10(2), 1-58. https://doi.org/10.1103/PhysRevSTPER.10.020119

Duran, M. (2016). The effect of the inquiry-based learning approach on student' s critical thinking, 12(12), 2887-2908. https://doi.org/10.12973/eurasia.2016.02311a

Education, T. (2015). Examining the Critical Thinking Dispositions and the Problem Solving Skills of Computer Engineering Students, 11(2), 353-361. https://doi.org/10.12973/eurasia.2015.1342a

Gregorio, J. B. (2015). Using Video Analysis , Microcomputer-Based Laboratories ( MBL ' s ) and Educational Simulations as Pedagogical Tools in Revolutionizing Inquiry Science Teaching and Learning, 1(1), 43-64.

Häkkinen, A. (2017). This is an electronic reprint of the original article . This reprint may differ from the original in pagination and typographic detail ., 23(1), 25-41. https://doi.org/10.1080/13540602.2016.1203772

Holmes, N. G., Wieman, C. E., \& Bonn, D. A. (2015). Teaching critical thinking. Proceedings of the National Academy of Sciences, 112(36), 11199-11204. https://doi.org/10.1073/pnas.1505329112

Howard, L. W., Tang, T. L., Austin, M. J., Bullington, K., Foote, D., Hennington, A., ... Clark, R. (2010). Journal of Business Ethics, (615), 1-38.

Kivunja, C. (2014). Do You Want Your Students to Be Job-Ready with 21st Century Skills? Change Pedagogies: A Pedagogical Paradigm Shift from Vygotskyian Social Constructivism to Critical Thinking, Problem Solving and Siemens' Digital Connectivism. International Journal of Higher Education, 3(3), 81-91. https://doi.org/10.5430/ijhe.v3n3p81

Loes, C. N., Salisbury, M. H., \& Pascarella, E. T. (2015). Student perceptions of effective instruction and the development of critical thinking: a replication and extension. Higher Education, 69(5), 823-838. https://doi.org/10.1007/s10734-014-9807-0

Manalo, E., \& Uesaka, Y. (2018). Students ' Spontaneous Use of Diagrams in Written Communication : Understanding Variations According to Purpose and Cognitive Cost Entailed Students 'Spontaneous Use of Diagrams in Written Communication: Understanding Variations, (February). https://doi.org/10.1007/978-3-662-44043-8

McCormick, N. J., Clark, L. M., \& Raines, J. M. (2015). Engaging Students in Critical Thinking and Problem Solving: A Brief Review of the Literature. Journal of Studies in Education, 5(4), 100. https://doi.org/10.5296/jse.v5i4.8249

Müller, K., Prenzel, M., Seidel, T., Müller, K., Prenzel, M., Seidel, T., ... Kjærnsli, M. (2016). Assessing Contexts of Learning, (December 2016). https://doi.org/10.1007/978-3-319-453576

Rönnebeck, S., Bernholt, S., \& Ropohl, M. (2016). Searching for a common ground - A literature review of empirical research on scientific inquiry activities. Studies in Science Education, 52(2), 161-197. https://doi.org/10.1080/03057267.2016.1206351

Ş, Ö. K., \& Özsoy, S. (2009). Pre-service teachers ' attitudes toward use of Vee diagrams in general physics laboratory, $1(3)$.

Thaiposri, P., \& Wannapiroon, P. (2015). Enhancing students' critical thinking skills through teaching and learning by inquiry-based learning activities using social network and cloud computing. Procedia - Social and Behavioral Sciences, 174, 2137-2144. https://doi.org/10.1016/j.sbspro.2015.02.013

Tiruneh, D. T., \& Cock, M. De. (2017). Measuring Critical Thinking in Physics : Development and Validation of a Critical Thinking Test in Electricity and Magnetism, 663-682. https://doi.org/10.1007/s10763-016-9723-0

Veresov, N. N. (2016). Perezhivanie as a Phenomenon and a Concept: Questions on Clarification and Methodological Meditations. Cultural-Historical Psychology, 12(3), 129148. https://doi.org/10.17759/chp.2016120308 
Wang, B. (2018). Effects of the Application of Computer Network Technology to Guided Discovery Teaching on Learning Achievement and Outcome, 14(7), 3269-3276.

Wartono, W., Hudha, M. N., \& Batlolona, J. R. (2018). How are the physics critical thinking skills of the students taught by using inquiry-discovery through empirical and theorethical overview? Eurasia Journal of Mathematics, Science and Technology Education, 14(2), 691697. https://doi.org/10.12973/ejmste/80632

Wartono, W., Rafafy Batlolona, J., \& Huda, C. (2018). Influence of Discovery Learning-Based Empirical- Theoretical Study Assisted by Animation Phet on the Physics Problem-Solving in High School, (February).

Wenning, C. J., \& Khan, M. A. (2011). Levels of Inquiry Model of Science Teaching : Learning sequences to lesson plans. Journal of Physics Teacher Education Online, 6(2), 17-20. 